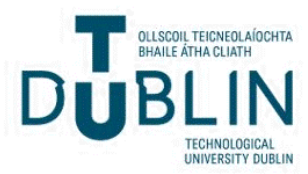

Technological University Dublin

ARROW@TU Dublin

\section{Nurturing 'buds of development': from outcomes to opportunities in early childhood practice}

\author{
Noirin Hayes \\ Technological University Dublin, noirin.hayes@tudublin.ie \\ Katarina Filipovic \\ Technological University Dublin, katarina.filipovic@tudublin.ie
}

Follow this and additional works at: https://arrow.tudublin.ie/cserart

Part of the Early Childhood Education Commons

\section{Recommended Citation}

Hayes, N. \& Filipović, K. (2018). Nurturing 'buds of development': from outcomes to opportunities in early childhood practice. International Journal of Early Years Education, vol. 26, no. 3, pg. 220-232.

https://doi.org/10.1080/09669760.2017.1341303

This Article is brought to you for free and open access by the Centre for Social and Educational Research at ARROW@TU Dublin. It has been accepted for inclusion in Articles by an authorized administrator of ARROW@TU Dublin. For more information, please contact arrow.admin@tudublin.ie, aisling.coyne@tudublin.ie, gerard.connolly@tudublin.ie.

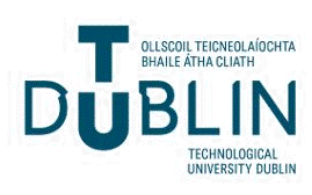




\section{Nurturing 'buds of development': from outcomes to opportunities in early childhood practice}

\section{Nóirín Hayes \& Katarina Filipović}

To cite this article: Nóirín Hayes \& Katarina Filipović (2018) Nurturing 'buds of development': from outcomes to opportunities in early childhood practice, International Journal of Early Years Education, 26:3, 220-232, DOI: 10.1080/09669760.2017.1341303

To link to this article: https://doi.org/10.1080/09669760.2017.1341303

电 Published online: 20 Jun 2017.

Submit your article to this journal $\pi$

Џll Article views: 220

View Crossmark data \lceil 


\title{
Nurturing 'buds of development': from outcomes to opportunities in early childhood practice
}

\author{
Nóirín Hayes $\mathbb{B}^{\mathrm{a}}$ and Katarina Filipović (D) $^{\mathrm{b}}$ \\ ${ }^{\mathrm{a} S}$ School of Education, Trinity College Dublin, Dublin, Ireland; ${ }^{\mathrm{b}}$ Dublin Institute of Technology, Dublin, Ireland
}

\begin{abstract}
The current future-focused, outcomes driven early childhood policy climate presents a danger that early years pedagogy will lose sight of the 'present' child. Increasingly policy support for early childhood education is built around an emphasis on preparing children for school and positioning it as a key element in enhancing society through preparing future citizens to become productive members of society. The measurable outcomes discourse, in emphasising product, renders invisible the critical contribution of the processes of everyday practice to children's development. To challenge and counteract the strong outcome discourse early years professionals must have confidence in their pedagogy. However, research suggests that those working in the early years may lack the language and strategies for supporting their educational practice. Using the bio-ecological model of development and drawing on the capabilities approach this paper calls for a shift in policy and pedagogical discourse from measuring competencies towards enhancing capabilities, from assessing outcomes towards providing rich, day-to-day learning opportunities. Such a shift in narrative could weaken the neo-liberal, outcome language of early childhood policy and refocus on supporting an early childhood pedagogy that would explicitly reflect current understanding of what is most beneficial to children's development and well-being and provide a powerful potential for change.
\end{abstract}

\section{ARTICLE HISTORY}

Received 11 December 2016 Accepted 30 May 2017

\section{KEYWORDS}

Proximal processes; child well-being; nurturing pedagogy; learning outcomes; learning opportunities

With evidence on the importance of the early years coming from psychological, sociological, educational and economic research policy-makers have ample evidence to support adequate investment in early years services. However, not all governments recognise the value of funding high-quality early childhood education for all children as a common good - rather they look to the future benefits of 'investing' in young children. The dominance of the economic argument is evident; it seems to make good sense to invest in services for young children because the return on investment in terms of future outcomes appears to be best when investment is in the younger child (Carneiro and Heckman 2003; OECD 2013). State investment in early education, however limited, has been fuelled by high expectations of the sector. Increasingly policy support for early childhood education is built around an emphasis on preparing children for school and reducing the likelihood of later school failure. Early childhood is positioned as a key element in 
enhancing society through preparing future citizen to become productive members of society. This 'future-focused, outcomes-driven, reductionist view of children as economic units' (Alcock and Haggerty 2013, 22) may not serve children well in their everyday life and development.

\section{Nurturing early learning environments}

Young children learn in a holistic, embodied and integrated way as they develop and make sense of their worlds and this has implications for practice. Enhancing well-being, even in the youngest children is achieved through encouraging their active participation in a way that is respectful of their unique being. The everyday experiences and opportunities that young children have to explore, play, develop and learn, the process of early childhood education, has a key role in supporting and enhancing young children's well-being. While discussing children's well-being in the context of education, Mashford-Scott, Church, and Tayler $(2012,233)$ argue that it can be seen as both 'an outcome and a process which facilitates children's progression towards all learning and development outcomes'. The authors link the sense of children's well-being with their ability to positively interact with the environment and utilise learning opportunities, as well with the overall quality of the early years programmes. Any consideration of the influences of contexts or experiences must ultimately be concerned with the 'present' child and her/his well-being in the here and now. Research tells us that the skills necessary to control and coordinate information, critical to positive everyday life experiences as well as later life and school success, are developed in the early years and provide the foundation for all later learning and development (Blair and Diamond 2008). Approaching the challenge of creating and supporting these positive early years experiences from the perspective of children's wellbeing provides a possible starting point for an alternative pedagogical discourse to the dominant 'future-focused, outcome driven' one. Children's well-being is increasingly acknowledged as an important contribution to their overall development and learning and understood as a core dimension of sustainable development. Kickbusch (2012) notes that children's well-being has a value in its own right while also contributing to a better and just society. Well-being is pivotal to realising children's rights and forms a central element of democratic practice. Personal well-being is a basis for personal mastery and a belief that one has a certain degree of control over one's self and the world.

Promoting positive well-being recognises and supports a child's right to actively contribute to the process of learning and reflects a growth in research into the value of children's participation in early education emerging from psychological, sociological and rights research (Dahlberg and Moss 2005; Hayes 2013; National Council for Curriulum and Assessment 2009). In early childhood pedagogy understanding the dynamics of the day-to-day development of individual children is critical to realising their participatory rights and provides insight into their varied levels of cognitive, affective and social development (Hayes 2010). Such an approach recognises the need to move towards a more inclusive and democratic practice, which trusts children and holds that, through discussion and interaction, we can all be moved towards some shared frame of reference (Leach and Moon 2000). It calls for a pedagogy that is child-sensitive, less patronising and more respectful of children's own role in their early development, both dynamic and normative. Within the current context of market driven, outcome discourse the 
value of, and necessity for, the everyday playful elements of quality early education are lost. Despite policy references to the need to balance care and education in early education, the evidence indicates that there continues to be a tendency to underestimate the educative role of caring (DCYA 2013, 2015). Hayes $(2007,2008)$ has argued that there is a value in attempting to reconceptualise care as nurture in order to enhance the opportunities to realise the educative dimension of care in practice. Introducing the idea of a 'nurturing pedagogy' she has proposed that an emphasis on nurture explicitly calls on early years educators to recognise and articulate the educative role of care, to reflect on the role of relationships and the importance of playful interaction, exploration, dialogue and collaborative learning in supporting young children's development. The word nurture provides a more engaging and active image than the word care; it conveys a more engaged level of interaction and requires the adult to actively nourish, rear, foster, train and educate the child through his/her practice.

In considering the features of such pedagogy to support and sustain high-quality early education Bronfenbrenner's bio-ecological model of development offers a useful framework (Bronfenbrenner and Morris 2006). The bio-ecological model emphasises that lives are lived interdependently through a network of shared relationships within and across systems of a society. Bronfenbrenner (2005) proposes that 'human development takes place through processes of progressively more complex reciprocal interaction between an active, evolving bio-psychological human organism and the persons, objects and symbols in its immediate environment' (620). To be effective these reciprocal interactions must occur regularly over time. Process is a core component, perhaps the defining component, of the bio-ecological model, and it comprises an emphasis on the importance of relationships. In particular, it highlights forms of interaction between the child and the environment called 'proximal processes' which operate over time, and are posited as primary mechanisms producing human development (Bronfenbrenner and Morris 2006). Proximal processes form the basis of day-to-day experiences and can facilitate the development of positive, generative dispositions of curiosity, persistence, responsiveness and engaged activity while inhibiting the more disruptive dispositions of impulsiveness; explosiveness; distractibility or apathy, inattentiveness, unresponsiveness and feelings of insecurity (Bronfenbrenner and Morris 2006). They represent the essential ingredient in early education as it is through interactions with other children, with adults, with materials and with concepts that children learn about the world around them and their place within that world. Adults are of critical importance in facilitating these proximal processes and have a powerful role in providing for reciprocal interactions through creating contexts which facilitate development and which provide quality early learning environments. However, there are external factors that challenge efforts to provide such quality early education; factors which emphasise the product or outcome of early education rather than champion the process of the early education experience.

\section{Outcome driven early childhood practice}

Penn and Lloyd (2014) have expressed concern that, with the growth of the market model of childcare provision across a range of different welfare regimes it is becoming the dominant approach. A feature of this policy model is the commissioning of public service provision to private providers thus distancing policy-makers from any direct responsibility for 
the quality of the actual provision of services. In Ireland, across many areas of social policy, scholars have observed a shift towards this form of neo-liberalism in which '[p]ublic goods, related to social justice and redistribution, are increasingly privatised, while their distribution becomes more consumer driven and less based on rights derived from citizenship' (Murphy 2010,2). This is as true of the policy towards early childhood education as it is to other policy areas (Hayes 2015). Because investment in early childhood education is seen as an investment in the future, policy-makers consider it necessary to measure the value of such investment and the currency for such evaluation is the 'measureable outcome'. While it may be important to estimate the value for money of state investment in any particular policy area it is unfortunate that the outcomes used to estimate the effectiveness of early education tend to reflect a lack of understanding of both child development and early education. As Wood (2013) has pointed out, the dominance of the outcome agenda in early childhood education discourse has created particular difficulties in practice. Reflecting the dynamic and interacting levels of influence outlined by Bronfenbrenner (Bronfenbrenner and Morris 2006) we can see that, at the microsystem level of quality early education practice, qualified and experienced early year professionals recognise the importance of play as a central learning process in early childhood. However it is difficult for them to respond to the macro- and exosystem level demands for measurable outcomes as making the outcomes of play visible is a challenge (Lopez Boo, Caridad Araujo, and Tome 2016). This in turn can lead to inability to effectively advocate for a play-based, holistic learning in an increasingly outcomes oriented society.

While the expectations placed on early childhood education to achieve future-focused outcomes are misplaced they are, nonetheless, difficult to avoid. The influential outcomes discourse has been present in the Irish policy context since the publication of the Agenda for Children's Services (Office of the Minister for Children 2007) identified a commitment to supporting 'needs led and outcomes focused services' (8). This Agenda informed the Better Outcomes-Brighter Futures: National Policy Framework for Children and Young People (DCYA 2014) which identified five national outcomes for children:

1. Active and Healthy

2. Achieving in all areas of learning and development

3. Safe and protected from harm

4. Economic security and opportunity

5. Connected, respected and contributing. (vi)

The framework commits to supporting children in achieving these outcomes though a number of transformational goals, including support for parents and 'earlier intervention and prevention' (vi) and guides the reader to a series of commitments and responsibilities in supporting the achievement of the five national outcomes for all children.

While recent documents (DCYA 2014, 2015) have broadened the rationale for investing in early childhood from the original one of supporting parents into the labour market, a narrow focus on early education as a preparation for school and school success still remains. This focus, particularly for children in disadvantaged circumstances, has foregrounded policy attention on assessing literacy and numeracy outcomes as a measure of success. The Irish National Literacy and Numeracy Strategy (Department of Education 
and Skills 2011) recognised the significant role that early education plays in laying the foundations of literacy and numeracy noting that:

Early experiences that support the development of children's communication skills ... play a key role in the development of their literacy skills ... The knowledge, skills, attitudes and dispositions developed in these early years impact significantly upon their later learning experiences. (DES 2011, 10)

However, the strategy goes on to state that in the current economic climate difficult decisions have to be made to ensure:

the most efficient use possible of available resources and in many instances re-prioritise spending away from desirable but ultimately less important activities to enable us to improve the literacy and numeracy skills of the children and young people in our care.

(DES 2011, 15)

This reflects a move away from the integrated, holistic approach to early education supported by international research and implicit in the principles underpinning both Aistear: the Early Childhood Curriculum Framework (NCCA 2009) and the Primary School Curriculum (NCCA 1999) towards an emphasis on the visible and measurable outcomes of literacy and numeracy. Within such a future-focus policy context there is a danger that sight is lost of the 'present' child and the experiences they are having in their day-to-day early childhood education settings; a key contribution to children's ongoing development and well-being (Bronfenbrenner 2005; Kickbusch 2012).

The measurable outcomes discourse is particularly concerning as it influences parental and societal understandings and expectations of early education and early educational practice, moving it further away from a focus on play, which fosters quality interactions and relationship formation, towards a more school like pedagogy emphasising the development of 'basic skills' and the importance of 'school readiness' (Hayes 2013; Ring et al. 2015; Weisberg, Hirsh-Pasek, and Golinkoff 2013). This tendency towards the 'schoolification' of early childhood education can be seen, for instance, in the increased use of the term pre-school. Within the Irish context this trend is evident with the introduction in 2010 of a universal Free Pre-School Year (FPSY). When announced, the Minister for Finance argued that FPSY would enhance 'the subsequent educational achievement of students and in turn increase the return for State investment in education generally' (Department of Finance 2009) clearly positioning the initiative within the school ready and investment paradigm.

In her seminal study Marcon (2002) reports that children who have experienced more academically directed early years settings have significantly lower grades at the end of their sixth year in school than those from settings with more child-initiated activities. Research supports the view that children value and benefit in early education learning environments where they can make choices and have time to themselves (Wood 2013). The centrality of play is a key component of the unique nature of early years practice reflecting the underlying assumption that processes of play form the basis of childhood development. Research indicates that children learn best in an environment that allows them to explore, discover and play and that values both cognitive and social development (Pramling and Pramling-Samuelsson 2011; Siraj-Blatchford 2010). As a result, many early years curriculum frameworks have incorporated play as a means of learning for children 
(Pramling Samuelsson and Carlsson 2008). Studies show that high-quality settings with integrated curriculums that support both cognitive and social development lead to improved behaviour at later school years such as less classes failed. Furthermore, children that attended settings where curriculum supported child-initiated activities were more likely to be involved in community work and to have higher education plans at age of 23 (OECD, n.d.).

\section{Valuing process in early childhood}

Studies have found that it is not the provision of early education per se that matters but the quality and intensity of that provision for the individual children attending (Yoshikawa et al. 2015). High-quality early learning opportunities result in positive effects for children (Burchinal et al. 2010; OECD, n.d.) and children in low-income families appear to benefit most (Gormley 2007). In contrast, negative effects or no positive effects have been shown for children living in poverty, whose only access is to poor, or low-quality centre-based early childhood education (Votruba-Drzal, Coley, and Chase-Lansdale 2004; Yoshikawa et al. 2015). The outcomes discourse emphasises the importance of the product of early childhood education; it distances and renders invisible the contribution of the day-today practice in early childhood settings, the 'mediating pathways' (Duncan and Magnuson 2002) that are crucial to developing towards useful and enriching capabilities. Research confirms that it is the process of travelling the pathways rather than the destination that is critical to children's development and learning (Siraj-Blatchford 2009; Wood 2013).

Research consistently shows that safe, secure nurturing environments enhance child well-being, allowing time and providing a context for the establishment of underlying executive functions and life skills that allow children to progress socially and academically (Blair and Diamond 2008; Reid and Kagan 2015). This is true irrespective of where children spend their early years - and many young children experience a variety of different early learning environments in the early years before formal schooling.

While facilitating learning and the development of skills crucial to later school and social success, quality early education practice has an eye to the future but it is not, nor should it be, driven by the future. Traditionally early childhood education has valued social, interactive and integrating practices, which respect young children in their present and create secure, calm and caring environments closely linked to the children's home and community (Brooker, Blaise, and Edwards 2014).

A well-trained, professional workforce can provide the kind of quality early education that we know is most effective for positive development (EC 2014; Hayes 2015). The OECD (2006) has characterised a well-trained workforce as one which is (i) familiar with child development and subject material, (ii) recognises and responds to the dynamic and individual nature of development in the early years and (iii) works with an emerging curriculum, driven by the interests and experiences of the children and the opportunities afforded by the environment. A shift towards the more informal teaching practice demanded to create rich early learning experiences will require a significant shift in approach away from the traditional style of teaching, the style experienced by many teachers in their own education. Dewey was one of the first authors to suggest that the more informal the pedagogy, the greater the need for a formal structuring of the conceptual and physical learning environment (Bruner 1996; Dewey [1938] 1998; 
Gardner 1999). This structure does not require a particularly ordered or rigid routine or environment but rather can be expressed in pedagogy by the adults through careful, informed and reflective planning from a rich knowledge base. To challenge and counteract the impact of an outcome discourse at policy level on early educational practice early years professionals must have confidence in their pedagogy. However, research suggests that those working in the early years may lack the language and strategies for supporting their educational practice.

In a study of pedagogical effectiveness Moyles, Adams, and Musgrove (2002) noted that early year practitioners were reluctant to engage in pedagogical discussions and found it difficult to articulate or describe in any detail the specifics of their practice that were important to them or the values, beliefs and principles underpinning their practice. Stephen (2010) found support for this in her research where she found that early years educators are often willing to talk about what they plan for children and what they do with them but are less likely to discuss why they do things - what she called their underlying pedagogical perspective. This presents a challenge for the professional development of early education professionals at both pre-service and continuing professional development (Peeters et al. 2014). Baker (2014) and others (Barnett and O’Mahony 2006; Dewar et al. 2013) identify professional reflection as a pedagogical tool through which early educators can examine their current practices, ensure self-development and the provision of quality education, and to articulate their teaching philosophies. Such a focus could encourage on-going engagement in professional reflections to strengthen pedagogical aspects of early educational practice through which the profession could develop a stronger and more confident pedagogical voice.

\section{Providing a new language for practice}

To be heard above the powerful external voices demanding measurable child outcomes early years professionals require a language that allows them to explain why quality early years practice that is process focused is educationally and developmentally more fitting for young children. They also need the strength to reject the image of an idealised universal normative child characterised by the outcome discourse and highlight the value and role of a pedagogy that attends to the unique dynamic nature of the child in their immediate present. In seeking language to assist in giving voice to the importance of process in early education, it is worth revisiting the report of UNESCO's International Commission on Education for the Twenty-first Century Learning: The Treasure Within (1996) often referred to as the Delors Report. This report is regarded as a key reference to conceptualising education and learning worldwide (Tawil and Cougoureux 2013) and argues that:

... a broad encompassing view of learning should aim to enable each individual to discover, unearth and enrich his or her creative potential, to reveal the treasure within each of us. This means going beyond an instrumental view of education as a process one submits to in order to achieve specific aims (in terms of skills, capacities or economic potential), to one that emphasises the development of the complete person, in short learning to be. (Delors 1996, 86)

To this end the report identified four pillars of learning (i) Learning to know; (ii) Learning to do; (ii) Learning to live together and (iv) Learning to be. Although criticised as overly 
visionary and unrealistic by some the report is one which has been revisited a number of times. Tawil and Cougoureux $(2013,8)$ recognise that the visionary nature of the report has meant that it is not easy to translate into practice and conclude that it would be important to revisit the report in light of multifaceted societal change observed worldwide since the 1990s'. The vision of education and learning articulated in the Delors Report provides a valuable alternative view of education to that of the current dominant utilitarian discourse. The four pillars of learning provide an excellent educational context within which to consider an emerging theoretical frame that could provide a helpful language with which to articulate the crucial role of the process nature of effective early childhood education (Draxler and Carneiro 2008). Of particular interest are the possibilities of early education in facilitating children to learn to be and to learn to do. This resonates well with research into quality early childhood education, which highlights the potential of quality early learning environments that enhance children's development and well-being.

Quality models of early education are characterised by underpinning principles which present a view of the child as an active partner in the integrated and on-going process of learning reflecting a strong commitment to developing the social and affective dimensions of learning as well as the more traditional emphasis on cognitive development. Cultivating positive learning dispositions and feelings in young children leads to positive outcomes in social, linguistic and cognitive development and the skills necessary for later school success. This reflects research (Bruner 1996; Denham et al. 2012; Laevers 2002; Sylva et al. 2004) which confirms that the most important learning in early education has to do with the affective and difficult to measure aspects of development such as aspirations, social skills, motivation, organisation, learner identity and confidence. It is a holistic, adaptive approach to early education focusing on creating early learning opportunities to enhance well-being and links in to recent discourse on education as a site for creating individual capabilities. Nussbaum (2011) discusses ways to improve the quality of life and well-being of people globally and argues that the role of public policy, including early education policy, should be to create contexts within which individuals can flourish and develop personal capabilities. The 'capabilities approach' highlights the importance of education in assisting children develop fundamental capabilities which, in turn, help children think critically and creatively, solve problems, make informed decisions, manage change and communicate effectively. Capabilities are the possibilities for acting and doing and, for early childhood professionals, they afford a context for considering and articulating how the process of quality early education provides the opportunities for children in early years settings to realise their capabilities, to learn to be and to do. This will require a practice focus on both providing and realising learning and development opportunities.

Considering early education from a 'capabilities approach' moves the pedagogical focus from a competence and outcomes one and challenges early years educators to consider what a child is actually able to do and reflect on how their practice exhibits a sensitivity to providing opportunities for each child reflecting their individual dynamic of development and learning. It also allows consideration of the extent to which early learning environments are enabling for children. Vygotsky (1978) has emphasised the importance of being in the moment and attending to the present in education, nurturing the 'buds of development'. He argued that pedagogy should be directed towards supporting the ripening function, the flowering or budding, of the child rather than towards producing the ripe, final fruit and highlighted the importance of the process of development over the 
end product. There is a resonance here with the concern that the pressure to focus on achieving measurable learning outcomes - arguably the fruits of early childhood education - can direct day-to-day practice towards achieving these distal outcomes without recognising that it is, in fact, providing the process for arriving at these outcomes that is the role of the early educator.

\section{Moving from an outcomes to an opportunities focus in practice}

Research is clear that the role of the adult in early education is central (Peeters et al. 2014). Recognising the centrality of pedagogy to effective early education is a challenge and requires extensive knowledge accompanied by a trust in the ability and interest of young children to learn. Well-trained and supported early years professionals are confident in their knowledge of the sophisticated nuances of child development; recognise and respond to both the normative and dynamic dimensions of development and are respectful and sympathetic listeners who negotiate meanings rather than impose them. Early years professionals working in this way provide a content-rich environment but do not come equipped with a fixed corpus of knowledge; rather, they provide opportunities for children, encouraging their play, helping them find their own meaning in a shared learning environment. Such practice, manifest in a nurturing pedagogy, embodies a trust in the educative value of care and confidence in the power of proximal processes, the day-to-day reciprocal interactions, to drive development and learning. Its aim is to provide and enrich early learning opportunities in responsive and relational environments rather than allow practice to be driven by a need to achieve externally prescribed outcomes. Pre-service education and continuing professional development which highlights these dimensions of early education pedagogy and builds in pedagogical reflection as a core dimension of education could help strengthen professional identity and confidence among early education practitioners. This, in turn, could strengthen the professional voice to raise awareness among parents and policy-makers of the key role of process in effective, quality early education.

Reconceptualising and articulating early education pedagogy from an opportunity focus could drive policy change away from the current neo-liberal, outcome driven language of early childhood education policy, which can negatively impact on early educational practice. Focusing attention on the process of creating early learning opportunities that enhance children's capabilities to be and to do (Delors 1996) could enhance children's development and learning. To achieve such a shift requires orienting early years practice towards the dynamic of children's development - foregrounding both process and opportunity. It rejects a focus on the static measurement of learning which foregrounds product and outcome. Such a shift in pedagogical focus and language could strengthen pedagogical reflection, enhance professional self-development and provide practitioners with the knowledge and confidence necessary to articulate and defend their pedagogical philosophy. It could be a powerful potential for change.

\section{Conclusion}

One of the challenges in translating research knowledge into practice is that practice happens in a real-world context. Contemporary research and literature confirms the 
importance of the early education professional in early education settings, particularly their skills of attending to the dynamic nature of development and informing such attention with increased knowledge and understanding of the components of the early educational process. However, the context of early education practice is also influenced by the prevailing education policy context outlining national aims for education and explicit outcomes to achieve such aims.

Outcomes provide an excellent organising frame for policy-makers but outcome driven early education practice can be problematic. Strengthening the voice of those working closest with children in early education to highlight the importance of creating and attending to the everyday opportunities available to children in quality early learning environments could shift the pedagogical discourse from responding to the pressures of outcomes focused policy. Such a reform would lay a strong foundation in practice for children to learn to be and learn to do and from which children could progress through into a future few of us can imagine.

\section{Disclosure statement}

No potential conflict of interest was reported by the authors.

\section{ORCID}

Nóirín Hayes (1) http://orcid.org/0000-0001-8086-5474

Katarina Filipović (D) http://orcid.org/0000-0003-4270-8202

\section{References}

Alcock, S., and M. Haggerty. 2013. "Recent Policy Developments and the 'Schoolification' of Early Childhood Care and Education in Aotearoa New Zealand." Early Childhood Folio 17 (2): 19-33.

Baker, F. S. 2014. "A Pathway to Play in Early Childhood Education Developed Through the Explicit Modelling of Reflective Practice in Teacher Education in Abu Dhabi, UAE." Reflective Practice 15 (2): 203-217.

Barnett, B. G., and G. R. O’Mahony. 2006. "Developing a Culture of Reflection: Implications for School Improvement.” Reflective Practice 7 (4): 499-523.

Blair, C., and A. Diamond. 2008. "Biological Processes in Prevention and Intervention: The Promotion of Self-Regulation as a Means of Preventing School Failure." Development and Psychopathology 20: 899-911.

Bronfenbrenner, U., ed. 2005. Making Human Beings Human: Bioecological Perspectives on Human Development. London: Sage.

Bronfenbrenner, U., and P. A. Morris. 2006. “The Bioecological Model of Human Development." In Handbook of Child Psychology, Vol. 1: Theoretical Models of Human Development, edited by W. Damon and R. M. Lerner, 6th ed., 793-828. New York, NY: John Wiley.

Brooker, E., M. Blaise, and S. Edwards, eds. 2014. SAGE Handbook of Play and Learning in Early Childhood. London: Sage.

Bruner, J. 1996. The Culture of Education. Cambridge, MA: Harvard University Press.

Burchinal, M., N. Vandergrift, R. Pianta, and A. Mashburn. 2010. "Threshold Analysis of Association between Child Care Quality and Child Outcomes for Low-Income Children in Pre-Kindergarten Programs." Early Childhood Research Quarterly 25: 166-176.

Carneiro, P., and J. Heckman. 2003. Human Capital: Working Paper 9495. Cambridge, MA: National Bureau of Economic Research. 
Dahlberg, G., and P. Moss. 2005. Ethics and Politics in Early Childhood Education. London: Routledge Falmer.

Delors, J. 1996. Learning: The Treasure Within. Paris: UNESCO.

Denham, S. A., H. Bassett, M. Mincic, S. Kalb, E. Way, T. Wyatt, and Y. Segal. 2012. "SocialEmotional Learning Profiles of Preschoolers' Early School Success: A Person-Centered Approach.” Learning and Individual Differences 22 (2): 178-189.

DCYA (Department of Children and Youth Affairs). 2013. Right from the Start: Report of the Expert Advisory Group on the Early Years Strategy. Dublin: Department of Children and Youth Affairs.

DCYA (Department of Children and Youth Affairs). 2014. Better Outcomes-Brighter Futures National Policy Framework for Children and Young People. Dublin: Government Stationery Office.

DCYA (Department of Children and Youth Affairs). 2015. Report of the Inter-Departmental Working Group: Future Investment in Childcare in Ireland. Dublin: Government Stationery Office.

Department of Finance. 2009. "Financial Statement of the Minister for Finance. Mr. Brian Lenihan T.D., 7 April 2009.” Accessed April 18, 2013. http://budget.gov.ie/budgets/2009Supp/ FinancialStatement.aspx.

DES (Department of Education and Skills). 2011. Literacy and Numeracy for Learning and Life The National Strategy to Improve Literacy and Numeracy among Children and Young People 2011-2020. Dublin: Department of Education and Skills.

Dewar, B. A., J. E. Servos, S. L. Bosacki, and R. Coplan. 2013. "Early Childhood Educators' Reflections on Teaching Practices: The Role of Gender and Culture." Reflective Practice 14 (3): 381-391.

Dewey, J. [1938] 1998. Experience and Education. West Lafayette, IN: Kappa Delta Pi.

Draxler, A., and R. Carneiro. 2008. "Editorial." European Journal of Education 43 (2): 145-148.

Duncan, G., and K. A. Magnuson. 2002. "Economics and Parenting." Parenting Science \& Practice 2: 437-450.

EC (European Commission). 2014. “Towards a European Quality Framework in Early Childhood Education and Care.” Director General Education and Care. ECEC/ESL Stakeholder Meeting March 31, 2014.

Gardner, H. 1999. The Disciplined Mind: What All Students Should Understand. New York, NY: Simon \& Schuster.

Gormley, W. T. 2007. "Early Childhood Care and Education: Lessons and Puzzles." Journal of Policy Analysis and Management 26: 633-671.

Hayes, N. 2007. "Perspectives on the Relationship Between Education and Care in Early Childhood." Background Paper Prepared for the National Council for Curriculum and Assessment. Dublin: National Council for Curriculum and Assessment.

Hayes, N. 2008. "Teaching Matters in Early Educational Practice: The Case for a Nurturing Pedagogy." Early Education and Development 19 (3): 430-440.

Hayes, N. 2010. "Childcare? Early Childhood Education and Care? Towards an Integrated Early Years Policy for Young Children in Ireland." Early Years: An International Journal of Research and Development 30 (1): 67-78.

Hayes, N. 2013. Early Years Practice: Getting It Right from the Start. Dublin: Gill and Macmillan. Hayes, N. 2015. "Troubling Outcomes: A Challenge for Early Childhood Education.” An Leanbh Óg - The OMEP Ireland Journal of Early Childhood Studies 9: 13-28.

Kickbusch, I. 2012. Learning for Well-Being: A Policy Priority for Children and Youth in Europe. A Process for Change, with the collaboration of Jean Gordon \& Linda O' Toole. Drafted on behalf of the Learning for Well-Being Consortium of Foundations in Europe. Brussels: Universal Education Foundation.

Laevers, F., ed. 2002. Research on Experiential Education: A Selection of Articles. Leuwen: Centre for Experiential Education.

Leach, J., and B. Moon. 2000. Learners and Pedagogy. London: Sage.

Lopez Boo, F., M. Caridad Araujo, and R. Tome. 2016. "How is Child Care Quality Measured?: A Toolkit.” Inter-American Development Bank. doi:10.18235/0000242. 
Marcon, R. A. 2002. "Moving up the Grades: Relationship between Preschool Model and Later School Success." Early Childhood Research \& Practice 4 (1): 1-23.

Mashford-Scott, A., A. Church, and C. Tayler. 2012. "Seeking Children's Perspectives on their Wellbeing in Early Childhood Settings." International Journal of Early Childhood 44 (3): 231247.

Moyles, J., S. Adams, and A. Musgrove. 2002. SPEEL: Study of Pedagogical Effectiveness in Early Learning. London: Department for Education and Skills.

Murphy, M. 2010. "What Future Lies Ahead for the Irish Welfare State?" Irish Journal of Public Policy 2 (1). Accessed October, 18, 2015. http://publish.ucc.ie/ijpp/2010/01/murphy/02/en.

NCCA (National Council for Curriculum and Assessment). 1999. Primary School Curriculum. Dublin: National Council for Curriculum and Assessment.

NCCA (National Council for Curriculum and Assessment). 2009. Aistear: The Early Childhood Curriculum Framework. Dublin: National Council for Curriculum and Assessment.

Nussbaum, M. 2011. Creating Capabilities: The Human Development Approach. Cambridge, MA: Harvard University Press.

Office of the Minister for Children. 2007. Agenda for Children's Services. Dublin: Department of Health and Children.

OECD (Organisation for Economic Co-operation and Development). 2006. Starting Strong II: Early Childhood Education and Care 11. Paris: OECD.

OECD (Organisation for Economic Co-operation and Development). 2013. Education Indicators in Focus: How do Early Childhood Education and Care (ECEC) Policies, Systems and Quality Vary Across OECD Countries? Paris: OECD.

OECD (Organisation for Economic Co-operation and Development). n.d. "Encouraging Quality in Early Childhood Education and Care (ECEC).” Research Brief: Curriculum Matters. http://www. oecd.org/education/school/49322232.pdf.

Peeters, J., C. Cameron, A. Lazzari, B. Peleman, I. Budginaite, H. Hauari, and H. Siarova. 2014. Impact of Continuous Professional Development and Working Conditions of Early Childhood Education and Care Practitioners on Quality, Staff-Child Interactions and Children's Outcomes: A Systematic Synthesis of Research Evidence. Gent: VBJK.

Penn, H., and E. Lloyd. 2014. "How can the Government Ensure that Early Care and Education is of High Quality in a Market System? Learning from International Experience." In Start Strong. 2014. Childcare: Business or Profession, 11-52. Dublin: Start Strong.

Pramling, N., and I. Pramling-Samuelsson. 2011. Educational Encounters: Nordic Studies in Early Childhood Didactics. Dordrecht: Springer.

Pramling Samuelsson, I., and M. A. Carlsson. 2008. "The Playing Learning Child: Towards a Pedagogy of Early Childhood." Scandinavian Journal of Educational Research 52 (6): 623-641.

Reid, J. L., and S. L. Kagan. 2015. A Better Start: Why Classroom Diversity Matters in Early Education. Washington, DC: Century Foundation and the Poverty and Race Research Action Council.

Ring, E., M. Mhic Mhathúna, M. Moloney, N. Hayes, D. Breatnach, P. Stafford, D. Carswell, et al. 2015. An Examination of Concepts of School-Readiness among Parents and Educators in Ireland. Dublin: Department of Children and Youth Affairs. www.dcya.ie.

Siraj-Blatchford, I. 2009. "Conceptualising Progression in the Pedagogy of Play and Sustained Shared Thinking in Early Childhood Education: A Vygotskian Perspective." Educational and Child Psychology 26 (2): 77-89.

Siraj-Blatchford, I. 2010. "A Focus on Pedagogy: Case Studies of Effective Practice." In Early Childhood Matters: Evidence from the Effective Pre-school and Primmary Education Project, edited by K. Sylva, E. Melhuish, P. Sammons, I. Siraj-Blatchford, and B. Taggart, 149-165. London: Routledge.

Stephen, C. 2010. "Pedagogy: The Silent Partner in Early Years Learning." Early Years: An International Research Journal 30 (1): 15-28.

Sylva, K., E. Melhuish, S. Sammons, I. Siraj Blatchford, and B. Taggart. 2004. The Effective Provision of Pre-School Education (EPPE) Project: Final Report. London: Institute of Education/Surestart. 
Tawil, S., and M. Cougoureux. 2013. Revisiting Learning: The Treasure Within - Assessing the Influence of the 1996 Delors Report: UNESCO Education Research and Foresight: Occasional Papers. Paris: UNESCO.

Votruba-Drzal, E., R. L. Coley, and L. Chase-Lansdale. 2004. "Child Care and Low-Income Children's Development: Direct and Moderated Effects.” Child Development 75 (1): 296-312.

Vygotsky, L. 1978. Mind in Society: The Development of Higher Psychological Processes. Cambridge, MA: Cambridge University Press.

Weisberg, D. S., K. Hirsh-Pasek, and R. M. Golinkoff. 2013. “Guided Play: Where Curricular Goals Meet a Playful Pedagogy." Mind, Brain, and Education 7 (2): 104-112.

Wood, E. 2013. Play, Learning and the Early Childhood Curriculum. 3rd ed. London: Sage.

Yoshikawa, H., C. E. Snow, M. C. Barata, C. J. Gomez, D. Leyva, E. Treviño, C. Weiland, et al. 2015. "Experimental Impacts of a Teacher Professional Development Program in Chile on Preschool Classroom Quality and Child Outcomes." Developmental Psychology 51 (3): 309-322. 